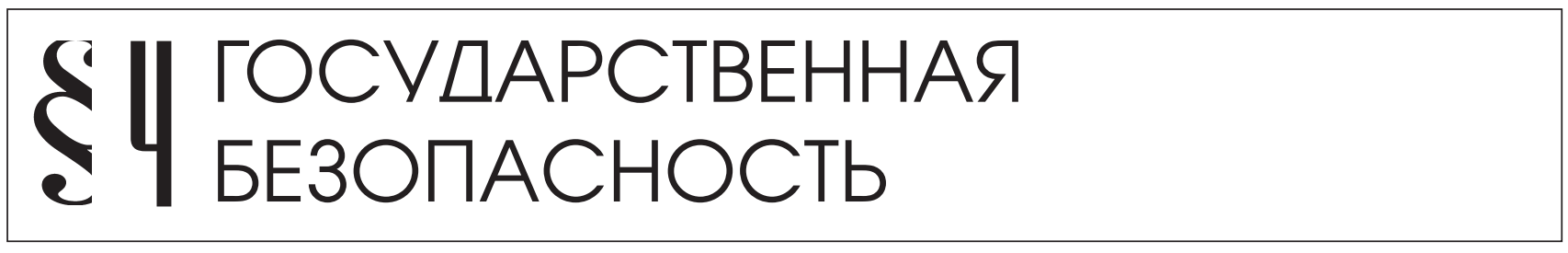

Кременская М.H.

\title{
ЗАКЛЮЧЕНИЕ КОНТРАКТА О ПРОХОЖДЕНИИ ВОЕННОЙ СЛУЖБЫ В ОРГАНАХ ФЕДЕРАЛЬНОЙ СЛУЖБЫ БЕЗОПАСНОСТИ
}

\begin{abstract}
Аннотация: Предмет исследования составляют теоретико-правовые основы заключения контракта о прохождении военной службы и его содержания. Объектом исследования являются общественные отношения, складывающиеся при заключении контракта о прохождении военной службы. В статье автор рассматривает нормы материального и процессуального права, регулирующие вопросы заключения контракта и его содержание. Особое внимание уделяется принципам дополнения содержания контракта конкретными правами и обязанностями. Сравнительно-правовой анализ контрактов различных федеральных органов исполнительной власти позволил сформулировать предложения по совершенствованию правового регулирования типовой формы контракта о прохождении военной службы и контракта военнослужащих органов федеральной службы безопасности. Методологическую основу составила система общенаучных и специальных научных методов познания. Из общенаучных методов - анализ, синтез, индукиия, дедукиия, сравнение; специальных научных методов использовался сравнительно-правовой метод. Научная новизна заключается в полученных отдельных теоретических положениях, направленных на совершенствование правового регулирования содержания контракта о прохождении военной службы. В частности, автором предложены для законодательного закрепления принципы дополнения содержания контракта военнослужащих конкретными правами и обязанностями, среди которых принципы «достаточности» и «неразрывной связи условий контракта с юридической ответственностью военнослужащего». Ключевые слова: Военная служба, контракт военнослажащего, условия контракта, государственная служба, ФСБ, содержание контракта, военнослужащий, госслужащий, коррупия, юридическая ответственность.

Abstract: The subject of this research consists in the theoretical-legal basis of signing a military service contract and its content. The object of the research is the public relations that form at the time of entering into the military service contract. The article examines the norms of material and procedural law that regulates the issues of entering into contract and its content. A special attention is given to the principles of making addendums to the content of the contract with specific rights and responsibilities, among which are the principles of "sufficiency" and "unbreakable ties between the terms of the contract and the legal liability of the member of the armed forces". The comparative-legal analysis of the contracts of various federal branches of law enforcement allowed formulating proposals for improving the standard contract for military service and the service contract for military personnel in the Federal Security Service.
\end{abstract}

Keywords: Content of the contract, federal security service, civil service, terms of the contract, military contract, military service, military personnel, civil servant, corruption, legal liability.

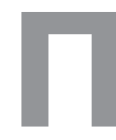
равовой основой заключения контракта о прохождении военной службы в органах федеральной службы безопасности (далее- органы безопасности) и его содержания являются Федеральный закон «О воинской обязанности и военной службе», Положение о порядке прохождения военной службы, а также нормативные правовые акты ФСБ России $[1,2]$. Вместе взятые, нормативные правовые акты составляют определенную систему, позволяющую обеспечивать реализацию целей и задач военной службы, защищать права и свободы военнослужащих. Однако правоприменительная практика в данной сфере свидетельствует о наличии многочисленных пробелов.

Заключение контракта о прохождении военной службы в органах безопасности может рассматриваться, с одной стороны, как необходимый элемент деятельности субъектов (кандидата на военную службу и уполномоченных должностных лиц органа безопасности) при поступлении на военную службу, с другой стороны, как один из юридических фактов, с которым законодатель 
связывает возникновение военно-служебных отношений [24]. В рамках данной статьи рассмотрим деятельностный подход к исследованию данного института.

Оформление военно-служебных отношений путем заключения добровольного соглашения (контракта о прохождении военной службы) в нашей стране начало осуществляться с принятием Закона Российской Федерации от 11 февраля 1993 г. «О воинской обязанности и военной службе».

В результате анализа законодательства о прохождении военной службы можно сделать вывод, что контракт заключается между гражданином (иностранным гражданином) и от имени Российской Федерации - Министерством обороны России или иным федеральным органом исполнительной власти, в котором федеральным законом предусмотрена военная служба. В контракте закрепляется: добровольность поступления гражданина на военную службу; срок, в течение которого он обязуется ее проходить; условия контракта.

В контракте также указываются: воинское звание, фамилия, имя и отчество гражданина, заключившего контракт, число, месяц и год его рождения; наименование федерального органа исполнительной власти, с которым заключается контракт, должность, воинское звание, фамилия и инициалы должностного лица, подписывающего контракт от имени этого органа; Вооруженные Силы Российской Федерации, другие войска, воинские формирования или органы, где гражданин будет проходить военную службу; даты подписания контракта гражданином и должностным лицом от имени федерального органа исполнительной власти [3].

В соответствии с п. 5 ст. 4 Положения о порядке прохождения военной службы условия контракта включают:

обязанность гражданина (иностранного гражданина) проходить военную службу в Вооруженных Силах Российской Федерации, других войсках, воинских формированиях или органах в течение установленного контрактом срока;

добросовестно исполнять все общие, должностные и специальные обязанности военнослужащих, установленные законодательством;

право гражданина (иностранного гражданина) на соблюдение его прав и прав членов его семьи, включая получение социальных гарантий и компенсаций, установленных законодательством, определяющим статус военнослужащих и порядок прохождения военной службы.

После подписей сторонами контракта указываются дата и номер приказа соответствующего должностного лица, в котором объявлено о вступлении в силу.
Анализ законодательства о прохождении военной службы позволяет определить порядок заключения контракта о прохождении военной службы следующим образом:

1) содержание контракта включает в себя указание на стороны, срок и условия;

2) предметом контракта являются военно-служебные отношения;

3) срок прохождения военной службы по контракту законодательством предусматривается различный, в зависимости от воинской должности, на которую поступает кандидат;

4) контракт заключается в соответствии с Типовой формой контракта о прохождении военной службы, которая включает в себя указание на стороны, срок, права и обязанности сторон, заключительные положения [3];

5) руководитель федерального органа исполнительной власти, в котором предусмотрена военная служба, вправе установить конкретные права и обязанности военнослужащих, предусмотренные законодательством Российской Федерации, обусловленные особенностями их военной службы.

Итак, можно выделить следующие особенности правового регулирования заключения контракта о прохождении военной службы:

1) порядок заключения контракта, его содержание, типовая форма установлены нормами военно-административного законодательства;

2) особый предмет и объект контракта: предметом являются общественные отношения в процессе прохождения военной службы; объектом - публичный интерес в сфере обороны и безопасности государства;

3) свобода согласования условий контракта не применима к контракту военнослужащего;

4) специальный субъектный состав: одной из сторон контракта является федеральный орган исполнительный власти, в котором федеральным законом предусмотрена военная служба, т.е. участник публично-правовых отношений, обладающий юридическивластными полномочиями по отношению к другой стороне; а также граждан (иностранный гражданин), соответствующий требованиям законодательства о прохождении военной службы;

5) особый административно-правовой статус субъектов состоит в том, что стороны контракта действуют в общегосударственных интересах. Можно согласиться с мнением ученого-административиста Д. Н. Бахраха, вступая в административные правоотношения, государственно-властный участник должен, реализуя общее благо, абстрагироваться от какой-либо своей 


\section{Право и политика 5 (185) • 2015}

собственной заинтересованности, подчинить ее общим интересам [16]. Данное утверждение распространяется и на военнослужащего;

6) неравенство сторон: с подписанием контракта возникают военно-служебные отношения, которые являются разновидностью административных, т.е. дальнейшее правовое регулирование осуществляется на основе метода власти и подчинения;

7) возможно одностороннее изменение условий контракта федеральным органом исполнительной власти, в котором федеральным законом предусмотрена военная служба, например, при изменении законодательства относительно вопросов прохождения военной службы;

8) применение мер ответственности со стороны федерального органа исполнительной власти, в котором федеральным законом предусмотрена военная служба, за неисполнение или ненадлежащее исполнение условий контракта;

9) особый порядок прекращения военной службы до истечения срока контракта - предусмотрен в случаях, строго установленных законодательством.

Важным для совершенствования правового регулирования заключения контракта о прохождении военной службы является рассмотрение в интересах исследования, помимо процессуальных норм, нормы материального права, поскольку последние предопределяют действие норм процесса [13]. В связи с этим необходимо рассмотреть как вопросы заключения контракта, так и его содержание, поскольку принципиальное отличие контракта о прохождении военной службы в других федеральных органах исполнительной власти от контракта военнослужащих органов безопасности заключается в его содержании.

Как уже отмечалось, руководитель федерального органа исполнительной власти, в котором законом предусмотрена военная служба, вправе дополнить содержание контракта о прохождении военной службы конкретными правами и обязанностями военнослужащих, предусмотренными законодательством, обусловленными особенностями их военной службы. То есть законодателем установлены два принципа, в соответствии с которыми условия контракта могут быть изменены и дополнены - предусматриваться нормой закона и отражать специиику военной службы в федеральном органе исполнительной власти.

Руководитель федерального органа исполнительной власти в области обеспечения безопасности воспользовался таким правом, значительно дополнив контракты военнослужащих органов безопасности $[1,2]$.
1. В связи с допуском к сведениям, составляющим государственную тайну, и необходимостью обеспечения ее сохранности - приказом ФСБ России от 10 июня 2011 г. № 246.

Если для военнослужащих Вооруженных Сил Российской Федерации допуск к сведениям, составляющим государственную тайну, оформляется в необходимых случаях [3], то для военнослужащих органов безопасности - оформление такого допуска является обязательным условием поступления на военную службу [4].

В соответствии с Федеральным законом «О воинской обязанности и военной службе» военнослужащий органов безопасности может быть досрочно уволен с военной службы в связи с отказом в допуске к государственной тайне или лишением указанного допуска (пп. «Г» П. 2 ст. 51).

2. В связи с соблюдением военнослужащими органов безопасности обязанностей, запретов, ограничений, предусмотренных законодательством о прохождении военной службы в органах безопасности, а также положений Кодекса этики и служебного поведения сотрудников органов безопасности - приказом ФСБ России от 20 сентября 2011 г. № 507.

Федеральным законом «О федеральной службе безопасности» устанавливаются особые условия прохождения военной службы, за несоблюдение которых ст. 51 Федерального закона «О воинской обязанности и военной службе» предусмотрено специальное основание увольнения с военной службы (пп. «е.2» п. 2 ст. 51).

Таким образом, перечисленные условия устанавливаются законодательством и отражают специфику прохождения военной службы в органах безопасности.

В соответствии с приказом ФСБ России от 10 июня 2011 г. № 507 в содержание контракта были включены обязательства по соблюдению требований законодательства Российской Федерации о государственной тайне. По сути, указанные обязательства представляют собой отдельный документ. Актуальным становится вопрос - насколько подробно нужно конкретизировать права и обязанности военнослужащих.

В работах многих ученых рассматривался вопросов возможности включения условий в содержание контракта о прохождении военной службы. На этот счет встречаются различные точки зрения. А. Т. Вахидов полагает, что пункт о дополнительных условиях тогда может быть включен в контракт, когда в нормативных актах появятся альтернативные условия прохождения военной службы в конкретных должностях [17]. Н. В. Антипьева считает, что детализация содержания 
контракта будет способствовать определенности в правах и обязанностях сторон [12].

Возможно, детализация и способствует определенности в правах и обязанностях сторон, для чего дублирование норм законодательства в контракте, и в каком объёме необходима такая детализация? Чтобы ответить на эти вопросы, следует определить отраслевую принадлежность контракта о прохождении военной службы и выделить принципы, в соответствии с которыми содержание контракта может быть дополнено.

Анализируя содержание контракта о прохождении военной службы, многие ученые отмечают наличие сходных признаков с трудовым соглашением [12, 19].

В соответствии с п. 1 ст. 10 Федерального закона «О статусе военнослужащих» посредством прохождения военной службы реализуется право военнослужащих на труд. То есть прохождение военной службы является особой разновидностью трудовой деятельности, имеющей ярко выраженную специфику из-за сферы ее применения - оборона и безопасность [24].

Однако, за исключением случаев прямой отсылки в законодательстве о прохождении военной службы к нормам трудового права, порядок заключения контракта о прохождении военной службы основан на нормах административного права, предусматривающих отношения «власть-подчинение» между сторонами договора [26].

Характерными чертами трудового договора выступают следующие: предметом трудового договора является соглашение об осуществлении работником определенной трудовой функции; трудовой договор выступает в качестве основания возникновения трудовых правоотношений; личный характер трудового договора; условия вырабатываются сторонами; воля стороны трудового договора автономна; договаривающиеся стороны формально-юридически равноправны; стороны трудового договора ответственны друг перед другом за его нарушение.

Можно выделить основные отличия контракта о прохождении военной службы от трудового договора: контрактом военнослужащего определяется не трудовая функция, а обязательство проходить военную службу в течение срока, установленного в контракте; контракт военнослужащего не есть основание возникновения правоотношений, а один из необходимых юридических фактов их возникновения; условия контракта не вырабатываются сторонами, а определены в законодательном порядке.

Так, контракт о прохождении военной службы призван не определять индивидуальные условия про- хождения военной службы, а зафиксировать факт добровольного двухстороннего волеизъявления о ее прохождении, а также срок, на который он заключается. Представляется, что императивный характер взаимоотношений между субъектами правоотношений при заключении, реализации и прекращении действия контракта о прохождении военной службы не позволяет сравнивать контракт с трудовым соглашением.

Существует другая точка зрения, с которой можно согласиться, что контракт о прохождении военной службы должен рассматриваться через призму системы государственной службы $[18,25]$. Известный ученый в области административного права С. Е. Чаннов выделяет служебные контракты с государственными гражданскими служащими, контракты со служащими правоохранительной службы и военнослужащими [27].

Системный закон о государственной службе устанавливает правовые основы поступления граждан на государственную службу и заключения контракта о прохождении государственной службы [5]. Так, ст. 12 указанного закона закрепляется положение, в соответствии с которым условия контрактов, порядок их заключения, а также основания и порядок прекращения их действия устанавливаются в соответствии с федеральным законом о виде государственной службы.

В интересах данного исследования рассмотрим отдельные вопросы правового регулирования содержания служебных контрактов государственных служащих (далее - госслужащие) государственной гражданской службы.

При поступлении на государственную гражданскую службу с гражданином Российской Федерации заключается служебный контракт. Федеральным законом от 27 июля 2004 г. № 79-ФЗ определяются содержание и форма служебного контракта [6]

Анализ законодательства о государственной гражданской службе позволил выявить, что в соответствии с примерной формой служебного контракта его содержанием является указание: на стороны контракта, предмет контракта, условия контракта, права и обязанности сторон, порядок оплаты труда, режим служебного времени и времени отдыха, срок действия контракта, иные условия контракта, ответственность сторон за неисполнение условий контракта, изменение и дополнение контракта, разрешение споров и разногласий, заключительные положения [7].

К существенным условиям служебного контракта закон относит: наименование замещаемой должности с указанием подразделения государственного органа, дату начала исполнения должностных обязанностей, 
DOI: $10.7256 / 1811-9018.2015 .5 .14993$

При цитировании этой статьи сноска на доі обязательна

\section{Право и политика 5 (185) • 2015}

права и обязанности, должностной регламент, виды и условия медицинского страхования и иные виды страхования, права и обязанности представителя нанимателя, условия профессиональной служебной деятельности, компенсации и льготы, предусмотренные за профессиональную служебную деятельность в тяжелых, вредных и (или) опасных условиях, режим служебного времени и времени отдыха, условия оплаты труда, нахождение должности, замещаемой гражданским служащим, в перечне должностей гражданской службы, по которым предусматривается ротация гражданских служащих.

Также в служебном контракте могут предусматриваться следующие условия: испытание при поступлении на гражданскую службу, неразглашение сведений, составляющих государственную и иную охраняемую федеральным законом тайну, и служебной информации, обязанность лица проходить гражданскую службу после окончания обучения в профессиональной образовательной организации или образовательной организации высшего образования, показатели результативности профессиональной служебной деятельности и связанные с ними условия оплаты его труда, иные условия, не ухудшающие положения гражданского служащего по сравнению с положением, установленным федеральным законодательством о государственной гражданской службе [6].

Содержание служебного контракта государственных гражданских служащих детально регламентируется законодательством. Законодатель предусмотрел разделение условий контракта на основные и иные условия, которые направлены на конкретизацию прав и обязанностей сторон.

Рассмотрим третью категорию контрактов - контракты со служащими правоохранительной службы. Поступлению на службу в таможенные органы посвящена вторая глава Федерального закона от 21 июля 2007 г. «О службе в таможенных органах Российской Федерации» [8]. Порядок заключения контракта и его типовая форма устанавливаются руководителем Федеральной таможенной службы Российской Федерации (далее - ФТС России) [9].

Приказом ФТС России от 1 декабря 2008 г. № 1504 определяется порядок заключения контракта [9]. В соответствии с п. 11 указанного приказа содержание контракта госслужащих таможенных органов состоит из обязательных и дополнительных условий.

Законодатель определяет, что обязательные условия контракта - это условия, по которым стороны должны достичь соглашения и зафиксировать их в контракте, к которым относятся: наименование должности с указанием структурного подразделения таможенного органа и места нахождения; дата начала исполнения служебных обязанностей; срок действия контракта; права и обязанности сотрудника; права и обязанности начальника таможенного органа; условия оплаты труда; режим служебного времени и времени отдыха; ответственность сторон за невыполнение взятых на себя обязательств.

Дополнительные условия - условия, вносимые в контракт по усмотрению сторон и конкретизирующие условия службы или устанавливающие дополнительные гарантии и компенсации сотруднику и членам его семьи. Стороны могут оговорить в контракте и любые другие условия, определяющие их дополнительные взаимные права и обязанности, которые не должны противоречить законодательству Российской Федерации.

Типовая форма контракта о службе в таможенных органах имеет указание на: стороны контракта, срок, права и обязанности сторон, условия оплаты труда, режим служебного времени и времени отдыха, дополнительные условия, порядок изменения условий контракта, заключительные положения. К дополнительным относятся условия о допуске к государственной тайне, получения второго высшего образования и пр.

Таким образом, анализ правового регулирования содержания служебного контракта государственных гражданских служащих, а также контрактов о службе в таможенных органах позволяет сделать вывод, что законодатель, в отличие от контракта о прохождении военной службы, разграничивает условия контракта на основные и иные (дополнительные). Можно выделить принципы дополнения содержания контракта госслужащих - условия контракта не должны противоречить законодательству Российской Федерации и индивидуализировать правовое положение госслужащего.

Принимая во внимание, что основным принципом построения и функционирования системы государственной службы является единство правовых и организационных основ государственной службы, предполагающее законодательное закрепление единого подхода к организачии государственной службь [5], законодатель пошел по пути конкретизации прав и обязанностей военнослужащих органов безопасности, дополнив контракты вышеперечисленными условиями, которые устанавливаются законодательством, отражают специфику прохождения военной службы в органах безопасности и неразрывно связаны с юридической ответственностью военнослужащего. 
Исходя из задач данной статьи, следует выделить еще и такой принцип, который должен учитываться в контрактах о прохождении службы госслужащими при конкретизации их прав и обязанностей как достаточность.

В научной литературе уже высказывалось мнение о том, что при включении дополнительных условий в контракт о прохождении военной службы достаточно включить в его содержание только отсылочную норму к требованиям закона [20]. В связи с этим под достаточностью следует понимать степень конкретизации прав и обязанностей госслужащих, которая позволит передать смысл требований закона отсылочной правовой нормой.

Анализ законодательства о прохождении государственной службы в различных федеральных органах исполнительной власти позволил выделить принципы дополнения условиями содержания контракта о прохождении военной службы. Это принципы: 1) единства правовых и организационных основ государственной службы, предполагающие законодательное закрепление единого подхода к организации государственной службы, в соответствии с которым иные (дополнительные) условия контракта включаются в содержание контракта в целях конкретизации прав и обязанностей сторон; 2) законодательного закрепления - условия контракта устанавливаются нормой именно федерального закона, а не подзаконного акта; 3) неразрывной связи соблюдения условий контракта с юридической ответственностью военнослужащего; 4) отражения специфики военной службы в федеральном органе исполнительной власти; 5) достаточности, под которым следует понимать степень конкретизации прав и обязанностей, которая позволит передать смысл отсылочной правовой нормой к требованиям федерального закона.

С учетом указанных принципов, текст контракта военнослужащих органов безопасности может быть уточнен (обязательства по соблюдению требований законодательства Российской Федерации о государственной тайне, закрепленные в контракте, могут рассматриваться как отдельный документ и подписываться при поступлении на военную службу) [1].

Типовую форму контракта о прохождении военной службы необходимо также дополнить следующими условиями.

Условиями в связи с утратой доверия к военнослужащему.

На сегодняшний день много говорится о коррупции, принято большое количество федеральных законов и подзаконных актов, направленных на профилактику, борьбу, минимизацию и ликвидацию последствий коррупционных правонарушений [10]. Среди явных угроз национальной безопасности руководством страны выделяется высокий уровень преступных посягательств коррупционной направленности [23]. В целях противодействия коррупции предусмотрены специальные основания увольнения в связи с утратой доверия для работников прокуратуры, сотрудников органов внутренних дел, таможенных органов, военнослужащих и др.

В научных публикациях особое внимание уделяется коррупции. В. В. Бараненков отмечает, что события на Украине, Египте, Ливии, Тунисе, Турции, Тайланде, в ряде других стран наглядно показывают, что коррупция активно используется «режиссерами» «цветных революций» в качестве повода для государственных переворотов. Борьба с коррупцией - условие выживания государства [14].

В настоящее время в стране активизирован процесс развития института государственной службы и параллельно с ним совершенствуется законодательство, имеющее антикоррупционную направленность [21].

Рост преступлений коррупционной направленности в органах безопасности обуславливает необходимость совершенствования мер по предупреждению коррупции, повышению ответственности военнослужащих, дополнения содержания контракта положениями антикоррупционного законодательства.

В связи с этим в соответствии с Федеральным законом «О воинской обязанности и военной службе» содержание контракта военнослужащих необходимо дополнить условиями, связанными с увольнением с военной службы, в связи с утратой доверия к военнослужащему (пп. «д.1», «д.2» п. 1 ст. 51).

Это следующие обязанности, запреты и ограничения военнослужащих.

1. Обязанность принятия мер по предотвращению и (или) урегулированию конфликта интересов, стороной которого является военнослужащий.

2. Обязанность представления военнослужащим сведений о доходах, расходах, об имуществе и обязательствах имущественного характера, а также о доходах, расходах, об имуществе и обязательствах имущественного характера своих супруги (супруга) и несовершеннолетних детей.

3. Запрет на участие военнослужащего или его доверенного лица в деятельности органа управления организации (международной или осуществляющей свою деятельность на территории Российской Федерации). Данный запрет предусматривается п. 7 ст. 10 Федерального закона «О статусе военнослужащих». 


\section{Право и политика 5 (185) 2015}

В ст. 16.1 Федерального закона «О федеральной службе безопасности» по сравнению с приведенной нормой Федерального закона «О статусе военнослужащих» расширено ограничение, касающееся управления юридическими лицами: военнослужащим запрещено участвовать в управлении как коммерческими, так и некоммерческими организациями.

4. Запрет на осуществление военнослужащим предпринимательской деятельности.

5. Запрет открывать и иметь счета (вклады), хранить наличные денежные средства и ценности в иностранных банках, расположенных за пределами территории Российской Федерации, владеть и (или) пользоваться иностранными финансовыми инструментами распространяется на военнослужащих, его супруги (супруга) и несовершеннолетних детей нормами соответствующего федерального закона [11]. Законодателем предпринята данная мера в целях обеспечения национальной безопасности, расширения инвестирования средств в национальную экономику и повышения эффективности противодействия коррупции. Применительно к Вооруженным Силам Российской Федерации действие указанного федерального закона распространяется на военнослужащих и государственных гражданских служащих, замещающих должности, назначение на которые и освобождение от которых осуществляются Президентом Российской Федерации (в частности, к данной категории относятся воинские должности, для которых штатом предусмотрены воинские звания высших офицеров) [22].

Как уже отмечалось, учитывая выделенный принцип связи условий контракта военнослужащих с основаниями увольнения с военной службы, содержание контракта может быть дополнено условиями в связи с нарушением запретов, ограничений и обязанностей, связанных с прохождением военной службы.

Указанные запреты, ограничения и обязанности предусматриваются п. 7 ст. 10 и ст. 27.1 Федерального закона «О статусе военнослужащих», которые были внесены Федеральным законом от 25 декабря 2008 г. № 280-Ф3 «О внесении изменений в отдельные законодательные акты Российской Федерации в связи с ратификацией Конвенции ООН против коррупции от 31 октября 2003 г. и Конвенции об уголовной ответственности за коррупцию от 27 января 1999 г. и принятием Федерального закона «О противодействии коррупции», позднее были конкретизированы Федеральным законом от 21 ноября 2011 г. № 329-Ф3.

В соответствии с п. 7 ст. 10 Федерального закона «О статусе военнослужащих» предусматриваются ограничения в связи с трудовой деятельностью военнослужащих. Ст. 27.1 указанного закона закрепляется, что на военнослужащего распространяются ограничения, запреты и обязанности, установленные Федеральным законом «О противодействии коррупции» и ст.ст. 17 , 18, 20 Федерального закона «О государственной гражданской службе».

Федеральным законом «О воинской обязанности и военной службе» предусматривается основание досрочного увольнения граждан, не выдержавших испытания при поступлении на военную службу (пп. «е» п. 2 ст. 51). В соответствии со ст. 34.1 указанного закона испытательной срок может быть установлен в отношении поступающих на военную службу на воинские должности, подлежащие замещению солдатами, матросами, сержантами и старшинами (за исключением обучающихся в военных профессиональных образовательных организациях или военных образовательных организациях высшего образования).

Анализ содержания контрактов госслужащих различных федеральных органов исполнительной власти позволяет выделить основные функции контракта: правоустанавливающую - с заключением контракта лицо приобретает статус госслужащего; информативную - госслужащий непосредственно получает информацию об условиях своей служебной деятельности; индивидуализирующую - в отношении госслужащего федерального органа исполнительной власти закрепляются конкретные права и обязанности, отражающие специфику прохождения службы в федеральном органе исполнительной власти.

Итак, сравнительно-правовой анализ контрактов госслужащих государственной гражданской, правоохранительной и военной службы позволил выделить принципы, требующие законодательного закрепления, с учетом которых контракт военнослужащих может быть дополнен.

К таким принципам можно отнести: единство правовых и организационных основ государственной службы; законодательное закрепление условий контракта (конкретных прав и обязанностей); неразрывную связь соблюдения условий контракта с юридической ответственностью военнослужащего; отражение специфики военной службы в федеральном органе исполнительной власти; достаточности.

Исходя, прежде всего, из информативной функции контракта и принципа неразрывной связи соблюдения условий контракта с юридической ответственностью военнослужащего, контракт о прохождении военной службы может быть дополнен условиями, связанными 
с увольнением с военной службы: в связи с утратой доверия к военнослужащему; в связи с нарушением запретов, ограничений и обязанностей, связанных с прохождением военной службы; в связи с испытательным сроком при поступлении на военную службу.

Контракт о прохождении военной службы в органах безопасности также требует уточнения его содержания с учетом принципа достаточности и заменой обязательств по соблюдению требований законодательства Российской Федерации о государственной тайне условием «неразглашение сведений, составляющих государственную тайну, в связи с оформлением соответствующего допуска».

В целях совершенствования правового регулирования контракта о прохождении военной службы в органах безопасности необходимо:

дополнить п. 6 ст. 4 Положения о порядке прохождения военной службы принципами «достаточности» и «неразрывной связи соблюдения условий контракта с юридической ответственностью военнослужащего», в соответствии с которыми руководитель федерального органа исполнительной власти вправе указать в типовой форме контракта конкретные права и обязанности; дополнить типовую форму контракта военнослужащих условиями, связанными с увольнением с военной службы, в связи с утратой доверия к военнослужащему и условиями, связанными с увольнением с военной службы, в связи с нарушением запретов, ограничений и обязанностей, установленных в связи с прохождением военной службы;

дополнить содержание контракта военнослужащих органов безопасности условием в связи с неразглашением сведений, составляющих государственную тайну, и оформлением соответствующего допуска к ним, исключив из текста контракта обязательства о соблюдении требований законодательства о государственной тайне.

\section{Библиография:}

1. Об организации работы по допуску к государственной тайне военнослужащих, федеральных государственных гражданских служащих, работников органов федеральной службы безопасности, а также граждан Российской Федерации, поступающих на федеральную государственную службу (работу) в органы федеральной службы безопасности : приказ ФСБ России от 10 июня 2011 г. № 246 // Рос. газ. - 2011. - 20 июля.

2. О контракте о прохождении военной службы и внесении изменения в приложение № 2 к приказу ФСБ России от 10 июня 2011 г. № 246 : приказ ФСБ России от 20 сент. 2011 г. № 507 // Рос. газ. - 2011. - 24 окт.

3. Вопросы прохождения военной службы : указ Президента Рос. Федерации от 16 сент. 1999 г. № 1237 // Собр. законодательства Рос. Федерации. - 1999. - № 39, ст. 4590.

4. О федеральной службе безопасности : федер. закон Рос. Федерации от 3 апр. 1995 г. № 40-Ф3 : принят Гос. Думой 22 февр. 1995 г. : одобр. Советом Федерации Федер. Собр. Рос. Федерации 15 марта 1995 г. : по сост. на 28 июня 2014 г. // Собр. законодательства Рос. Федерации. - 1995. - № 15, ст. 1269.

5. О системе государственной службы Российской Федерации : федер. закон Рос. Федерации от 27 мая 2003 г. № 58 -Ф3 : принят Гос. Думой 25 апр. 2003 г. : одобр. Советом Федерации Федер. Собр. Рос. Федерации 14 мая 2003 г. : по сост. на 17 дек. 2009 г. // Собр. законодательства Рос. Федерации. - 2003. - № 22, ст. 2063.

6. О государственной гражданской службе Российской Федерации : федер. закон Рос. Федерации от 27 июля 2004 г. № 79-Ф3 : принят Гос. Думой 7 июля 2004 г. : одобр. Советом Федерации Федер. Собр. Рос. Федерации 15 июля 2004 г.: по сост. на 28 дек. 2013 г. // Собр. законодательства Рос. Федерации. - 2004. - № 31, ст. 3215.

7. О примерной форме служебного контракта о прохождении государственной гражданской службы Российской Федерации и замещении должности государственной гражданской службы Российской Федерации : указ Президента Рос. Федерации от 16 февр. 2005 г. № 159 // Собр. законодательства Рос. Федерации. - 2005. - № 8, ст. 629.

8. О службе в таможенных органах Российской Федерации : федер. закон Рос. Федерации от 21 июля 2007 г. № $114-Ф 3$ : принят Гос. Думой 18 июня 1997 г. : одобр. Советом Федерации Федер. Собр. Рос. Федерации 4 июля 1997 г. : по сост. на 17 дек. 2009 г. // Собр. законодательства Рос. Федерации. - 1997. - № 30, ст. 3586.

9. Об утверждении Положения о порядке заключения контракта о службе в таможенных органах Российской Федерации и типовой формы контракта о службе в таможенных органах Российской Федерации : приказ ФТС России от 1 дек. 2008 г. № 1504 // Рос. газета. - 2009. - 1 апр.

10. О внесении изменений в отдельные законодательные акты Российской Федерации в связи с совершенствованием государственного управления в области противодействия коррупции : федер. закон Рос. Федерации от 21 нояб. 2011 г. № 329-Ф3 : принят Гос. Думой 2 нояб. 2011 г. : одобр. Советом Федерации Федер. Собр. Рос. Федерации 9 нояб. 2011 г.: по сост. на 28 июня 2013 г. // Собр. законодательства Рос. Федерации. - 2011. - № 48, ст. 6730.

11. О запрете отдельным категориям лиц открывать и иметь счета (вклады), хранить наличные денежные средства и ценности в иностранных банках, расположенных за пределами территории Российской Федерации, владеть и (или) пользоваться иностранными финансовыми инструментами : федер. закон Рос. Федерации от 7 мая 2013 г. № 79 -Ф3 : принят Гос. Думой 24 апр. 2013 г. : одобр. Советом Федерации Рос. Федерации от 27 апр. 2013 г. : по сост. на 7 мая 2013 г. // Собр. законодательства Рос. Федерации. - 2013. - № 19, ст. 2329. 
DOI: $10.7256 / 1811-9018.2015 .5 .14993$

При цитировании этой статьи сноска на dоі обязательна

\section{Право и политика 5 (185) 2015}

12. Антипьева Н. В. Контракт о прохождении военной службы как соглашение о труде // Российский юридический журнал. - 2006. - № 4.

13. Бабенко Н. А. Соотношение материальных и процессуальных норм в системе российского права : дис. ... канд. юрид. наук / Н. А. Бабенко. - Челябинск, 2013.

14. Бараненков В. В. Конфликт интересов на военной службе: понятие, сущность и признаки // Военное право : электрон. науч. изд. - 2014. - Вып. 1. Режим доступа: http://www.voennoepravo.ru (дата обращения: 12.12.2014).

15. Бараненкова И. В. О необходимости систематизации норм, регулирующих противодействие коррупции в военных организациях // Военное право : электрон. науч. изд. - 2014. - Вып. 3. Режим доступа: http://www.voennoepravo.ru (дата обращения: 12.12.2014).

16. Бахрах Д. Н. Административное право России : учеб. - 2 изд. перераб. и доп. - М. : НОРМА, 2010.

17. Вахидов А. Т. Организационно-правовые основы поступления граждан на военную службу по контракту в Вооруженных Силах Российской Федерации : дис. ... канд. юрид. наук / А. Т. Вахидов. - М. : ВУ, 1996.

18. Гришковец А. А. К вопросу о служебном праве // Государство и право. - 2013. - № 11.

19. Журавлев С. И. Правовые основы комплектования пограничных органов федеральной службы безопасности военнослужащими по контракту: учебно-метод. пособие. - М. : МВИ ФПС России, 2004.

20. Журавлев С. И. Правовое регулирование кадрового обеспечения федеральных органов государственной власти : монография / С. И. Журавлев. - М. : МГЮА, 2010.

21. Кандыбин Р. Сущность и типология конфликта интересов на государственной службе в военной организации государства // Военное право : электрон. науч. изд. - 2013. - Вып. 1. Режим доступа: http://www.voennoepravo.ru (дата обращения: 12.11.2013).

22. Корякин В. М. Антикоррупция-2013: законодательство совершенствуется // Право в Вооруженных Силах. - 2013. - № 12.

23. Корякин В. М. Коррупция в Вооруженных Силах: теория и практика противодействия: монография. - М. : За права военнослужащих, 2009.

24. Кудашкин А. В. Правовое регулирования военной службы в Российской Федерации : дис. ... д-ра юрид. наук / А. В. Кудащкин. - М. : РАГС, 2003.

25. Старилов Ю. Н. Служебное право России: уже реальность или пока научная гипотеза? // Правовая наука и реформа юридического образования - 2013. - № 3.

26. Уруков В. Н., Казаков С. Д., Полит О. И. Комментарий к Федеральному закону от 28 марта 1998 г. № $53-Ф 3$ «О воинской обязанности и военной службе» (постатейный) / отв. ред. Г. Н. Жуков. Режим доступа из КонсультантПлюс (дата обращения: 28.05.2014).

27. Чаннов С. Е. Служебный контракт: за и против // Современное право. - 2009. - № 12.

28. Я.В. Мирошниченко Совершенствование правового регулирования прохождения государственной правоохранительной службы в таможенных органах Российской Федерации. // Административное и муниципальное право. - 2011. - 1. - С. 8 - 17.

29. М.В. Костенников, А.В. Куракин, И.Н. Кошелев Административно-правовое регулирование обеспечения собственной безопасности и противодействия коррупции в органах внутренних дел (ч. 1). // Административное и муниципальное право. $-2011 .-1 .-$ С. $40-47$.

\section{References (transliterated):}

1. Antip’eva N. V. Kontrakt o prokhozhdenii voennoi sluzhby kak soglashenie o trude // Rossiiskii yuridicheskii zhurnal. - 2006. - № 4.

2. Babenko N. A. Sootnoshenie material'nykh i protsessual'nykh norm v sisteme rossiiskogo prava : dis. ... kand. yurid. nauk / N. A. Babenko. - Chelyabinsk, 2013.

3. Baranenkov V. V. Konflikt interesov na voennoi sluzhbe: ponyatie, sushchnost' i priznaki // Voennoe pravo: elektron. nauch. izd. - 2014. - Vyp. 1. Rezhim dostupa: http://www.voennoepravo.ru (data obrashcheniya: 12.12.2014).

4. Baranenkova I. V. O neobkhodimosti sistematizatsii norm, reguliruyushchikh protivodeistvie korruptsii v voennykh organizatsiyakh // Voennoe pravo : elektron. nauch. izd. -2014. - Vyp. 3. Rezhim dostupa: http://www.voennoepravo.ru (data obrashcheniya: 12.12.2014).

5. Bakhrakh D. N. Administrativnoe pravo Rossii : ucheb. - 2 izd. pererab. i dop. - M. : NORMA, 2010.

6. Vakhidov A. T. Organizatsionno-pravovye osnovy postupleniya grazhdan na voennuyu sluzhbu po kontraktu v Vooruzhennykh Silakh Rossiiskoi Federatsii : dis. ... kand. yurid. nauk / A. T. Vakhidov. - M. : VU, 1996.

7. Grishkovets A. A. K voprosu o sluzhebnom prave // Gosudarstvo i pravo. - 2013. - № 11.

8. Zhuravlev S. I. Pravovye osnovy komplektovaniya pogranichnykh organov federal'noi sluzhby bezopasnosti voennosluzhashchimi po kontraktu: uchebno-metod. posobie. - M. : MVI FPS Rossii, 2004.

9. Zhuravlev S. I. Pravovoe regulirovanie kadrovogo obespecheniya federal'nykh organov gosudarstvennoi vlasti : monografiya / S. I. Zhuravlev. - M. : MGYuA, 2010.

10. Kandybin R. Sushchnost' i tipologiya konflikta interesov na gosudarstvennoi sluzhbe v voennoi organizatsii gosudarstva // Voennoe pravo : elektron. nauch. izd. - 2013. - Vyp. 1. Rezhim dostupa: http://www.voennoepravo.ru (data obrashcheniya: 12.11.2013).

11. Koryakin V. M. Antikorruptsiya-2013: zakonodatel'stvo sovershenstvuetsya // Pravo v Vooruzhennykh Silakh. - 2013. - № 12. 
DOI: $10.7256 / 1811-9018.2015 .5 .14993$

При цитировании этой статьи сноска на dоі обязательна

Государственная безопасность

12. Koryakin V. M. Korruptsiya v Vooruzhennykh Silakh: teoriya i praktika protivodeistviya: monografiya. - M.: Za prava voennosluzhashchikh, 2009.

13. Kudashkin A. V. Pravovoe regulirovaniya voennoi sluzhby v Rossiiskoi Federatsii : dis. ... d-ra yurid. nauk/A. V. Kudashchkin. - M.: RAGS, 2003.

14. Starilov Yu. N. Sluzhebnoe pravo Rossii: uzhe real'nost' ili poka nauchnaya gipoteza? // Pravovaya nauka i reforma yuridicheskogo obrazovaniya - 2013. - № 3.

15. Urukov V. N., Kazakov S. D., Polit O. I. Kommentarii k Federal’nomu zakonu ot 28 marta 1998 g. № 53-FZ «O voinskoi obyazannosti i voennoi sluzhbe» (postateinyi) / otv. red. G. N. Zhukov. Rezhim dostupa iz Konsul'tantPlyus (data obrashcheniya: 28.05.2014).

16. Channov S. E. Sluzhebnyi kontrakt: za i protiv // Sovremennoe pravo. - 2009. - № 12.

17. Ya.V. Miroshnichenko Sovershenstvovanie pravovogo regulirovaniya prokhozhdeniya gosudarstvennoi pravookhranitel'noi sluzhby v tamozhennykh organakh Rossiiskoi Federatsii. // Administrativnoe i munitsipal'noe pravo. - 2011. - 1. - C. 8 - 17.

18. M.V. Kostennikov, A.V. Kurakin, I.N. Koshelev Administrativno-pravovoe regulirovanie obespecheniya sobstvennoi bezopasnosti i protivodeistviya korruptsii v organakh vnutrennikh del (ch. 1). // Administrativnoe i munitsipal'noe pravo. - 2011. - 1. - C. 40 - 47. 